\title{
Plot by Plot: Plotting Urbanism as an Ordinary Process of Urbanization
}

\author{
Ozan Karaman \\ Laboratoire Techniques, Territoires et Sociétés \\ LATTS, Univ Gustave Eiffel, CNRS, ENPC \\ F-77454 Marne-la-Vallée, France \\ ozan.karaman@enpc.fr \\ Lindsay Sawyer \\ Urban Studies and Planning \\ University of Sheffield \\ Sheffield, UK \\ 1.sawyer@sheffield.ac.uk \\ Christian Schmid \\ Department of Architecture \\ ETH Zurich \\ Zurich, Switzerland \\ schmid@arch.ethz.ch \\ Kit Ping Wong \\ Future Cities Laboratory \\ Singapore-ETH Centre \\ Singapore \\ tammywong111@gmail.com
}

\begin{abstract}
With this paper, we analyse an ordinary urban process, which has received little attention so far, and propose a new concept to take account of it: plotting urbanism. It is usually subsumed under terms like "urban informality" or "incremental urbanism" and not studied as a distinct process. In comparing Lagos, Istanbul and Shenzhen we captured four defining features of plotting urbanism: first, it unfolds in a piecemeal fashion with limited comprehensive planning. Second, it emerges from specific territorial compromises often resulting from conflicts between overlapping modes of territorial regulation, land tenure and property rights. Third, plotting is based on commodification of housing and land, which might accentuate socio-economic differentiations between property-owners, who often live in the same area, and their tenants.
\end{abstract}


The term "plotting" highlights the key role of the plot in the process. It also alludes to strategic acts of collaboration for individual and collective benefit.

Keywords: urbanisation processes, comparative urbanism, plotting urbanism, popular urbanisation, urban informality Introduction

\section{Introduction}

In parts of Istanbul, Shenzhen, Lagos and Kolkata, a large number of people live in urban areas that have developed plot-by-plot over time based on speculative and sometimes exploitative land and housing markets with limited official planning. These areas transform through incremental improvements to individual properties or the redevelopment of individual plots. Landlords, plot-owners, government officials, tenants, local elites and authority figures form complex alliances to act for individual or group gain through this specific urbanization process. They navigate, manipulate and circumvent unresolved contradictions and ambivalences, which often result from multiple overlapping modes of territorial regulation, land tenure and property rights. These areas are often densely built and vibrant, yet might lack public spaces, amenities and access to reliable infrastructure due to limited urban planning. People with low income, or without access to social housing or formal credit schemes, may find affordable land, property or rental housing in these areas. More resourceful individuals and communities might also engage in exploiting economic opportunities and political connections to generate profits through urban development. Even if each of these areas has distinctive features, we understand them as produced through a specific process of urbanization, which we call plotting urbanism, or plotting for short. In the literature, plotting has not been identified as a distinct process so far. In this article, we delineate this process of plotting urbanism, its characteristics and intrinsic logics and suggest a definition for further discussion and possible application in research and practice.

We conceptualised plotting urbanism in the framework of the project Patterns and Pathways of Planetary Urbanization in Comparative Perspective, in which we compared urban processes in eight large urban regions: Tokyo, Kolkata, Hong Kong/Shenzhen/Dongguan, Istanbul, Lagos, Paris, Mexico City and Los Angeles. ${ }^{i}$ In order to engage and facilitate discussions on changing urban landscapes, and to contribute to the creation of a more precise and differentiated vocabulary of urbanization, we identified a series of hitherto unrecognized 
urbanization processes that are often subsumed under broader and more generic concepts (see Schmid et al 2018). This project is strongly inspired by various calls from postcolonial perspectives to disrupt entrenched hierarchical imaginaries within urban theory, and to understand every urban experience as relevant to theory building (Robinson 2002, 2006; Roy 2009a). Various comparative approaches have been proposed for the generation of new conceptualizations of urbanization to go beyond regional divides and to think through diverse urban contexts (see e.g. Caldeira 2017; Robinson 2016; Schmid 2014; Shatkin 2017). Our own approach was further encouraged by Robinson's (2011) proposal to “compare the incommensurable" and to undertake "comparative experiments" (for a more detailed discussion of our comparative approach see Schmid et al 2018).

Our work is based on a transductive procedure, linking research and theory building through continuous feedback between the conceptual framework and empirical observations (see also Lefebvre 1996:151). On the theoretical level, we were informed by a multidimensional and process-oriented understanding of urbanization on the basis of Henri Lefebvre's threedimensional theory of the production of space (Lefebvre 1991 [1974]; see also Schmid 2008), and by the decentred perspective of planetary urbanization (Brenner and Schmid 2011, 2015; Schmid 2018). Thus, urban regions are not seen as bounded units, but as open configurations shaped by various urbanization processes stretching out over the territory. According to Lefebvre's theory, we define urbanization processes in a multidimensional way: we consider material interactions, territorial regulations, everyday experiences and the dialectical relationships between these three dimensions in order to reveal the dynamics of an urbanization process. Instead of emphasizing only one specific aspect (incremental forms of urbanisms, informality and/or illegality, commodification processes in everyday life, etc.), we look at the complex relationships between different aspects of social reality (for a detailed discussion see Schmid et al 2018; Schmid 2015). In our research, we applied a methodology that allowed for a thorough analysis of the concrete local and historical urban contexts, based on iterative rounds of detailed field research, mobile and multi-sited ethnography, interviews with inhabitants, exploratory mapping with experts, and a comprehensive consideration of a broad local scholarship. We finally identified and conceptualized a series of new urbanization processes through regular intensive comparative workshops of one to two weeks each involving the entire research team. We do not suggest that the resulting concepts have fixed definitions; rather, we understand them as revisable propositions for further examination and discussion. 
The concept of plotting urbanism is based on a somewhat counterintuitive selection of case studies, and despite a convincing set of characteristics holding this grouping together, extant terms and concepts kept pulling them apart. As we repeatedly compared the redevelopment of gecekondu neighbourhoods in Istanbul and bustee areas in Kolkata ${ }^{\mathrm{ii}}$, the formation of "tenement housing" in Lagos and of "urbanized villages" in Shenzhen, a distinct concept kept slipping in and out of focus. On the one hand, the empirical examples we were comparing could be simply seen as specific outcomes of general processes of urbanization or urban intensification. On the other hand, highly specific terms in each context, each with their own literature, such as gecekondu and more recently "post-gecekondu" (Esen 2011) in Turkey and "urbanized villages" (chengzhongcun) in China gave the appearance of incommensurability and impeded the recognition of similarities across time and space. In the end we considered that extant concepts to describe urbanization processes were inadequate to the task of bringing the different dimensions of these urban experiences together. Multiple terms could be applied to analyse the areas under discussion: aspects of urban regeneration are visible; physical improvements and increases in rents might point towards gentrification; some areas feature suburban characteristics; and with varying levels of official recognition and limited regulations, these areas are frequently described as "informal". Yet all these concepts fall short of addressing the specificity of the processes that we detected.

In particular, the concept of urban informality that seems to address the main feature of plotting urbanism created major problems for our analysis. The difficulties with the concept of urban informality are well-known and widely discussed (Caldeira 2017; McFarlane 2012; Roy 2009b; Roy and AlSayyad 2004; Schmid et al 2018; Streule et al 2020). ${ }^{\text {iii }}$ First of all, it is based on a binary conception, when in actuality the distinction between formal and informal forms of regulations are often highly blurred, and they often even overlap. Second, common definitions of informality rest on very broad understandings of formal and informal procedures, and therefore "informality" could take very different forms and be identified in highly diverse settings - including in affluent neighbourhoods. Indeed, one of the results of our own comparative analysis was to identify two distinct urbanization processes that are usually subsumed under the umbrella of "urban informality": "plotting urbanism" and "popular urbanization". We define "popular urbanization", which we could also observe in Istanbul, Lagos and Kolkata, as a people-led process of land appropriation and settlement building based on collective action, self-organization and the labour of inhabitants (Streule et al. 2020). In contrast, plotting urbanism is characterized by more individualized strategies of urban 
development and intensification of land use, strong processes of commodification and often a marked socioeconomic differentiation between property owners and tenants. Popular urbanization and plotting urbanism therefore refer to two distinct logics of urbanization resulting in different urban outcomes. This distinction is not clear-cut however. There might be hybrid or transitional forms, where aspects of popular urbanization and plotting urbanism could be observed at the same time in a given area. ${ }^{\text {iv }}$ Wider discussion, based on insights of different contexts, will be needed to explore the value of these terms.

In putting specific urbanization processes in Shenzhen, Lagos, Istanbul and Kolkata in conversation with each other, the contours of a discrete urbanization process with certain characteristics came to the fore, such as: consolidation and intensification of the built-up structure, incremental urban development, ambivalences in territorial regulations, landlordtenant relationships, land speculation and commodification particularly through rental housing. We finally arrived at the term plotting. The term is particularly useful for its many inferences: firstly it could refer to the subdivision of land into individual plots with fragmented ownership or entitlement. Secondly, it highlights the piecemeal plot-by-plot pattern of urbanization over large areas resulting in a more or less regular urban form that is clearly discernible in the urban fabric but emerges without an overarching plan. Thirdly, plotting alludes to controversial, strategic scheming, or even illegal actions in the production of the urban fabric, at the individual or group level. And lastly it evokes the multiple 'plot-lines' formed by official and non-official narratives about these places. ${ }^{\mathrm{v}}$

The following section places the concept of plotting urbanism in relation to the wider analytical context, and considers how to differentiate it from other closely related concepts. The paper will then present the three case studies of Lagos, Istanbul and Shenzhen before proposing a detailed definition of plotting urbanism and exploring some of the agendas and questions that this concept might raise.

\section{Towards a more specific vocabulary of urbanization}

Discomfort with the extant range of concepts to analyse urbanization processes has been expressed for some time, particularly by postcolonial scholars. Thus, a series of heuristic concepts have been generated over the last two decades in order to grasp some specific but fleeting aspects of "southern" urbanisms, such as "quiet encroachment" (Bayat 2000), 
“occupancy urbanism” (Benjamin 2008), “insurgent citizenship” (Holston 2008), “incremental urbanism” (McFarlane 2011), "the urban majority" (e.g. Simone and Rao 2012), and most recently "peripheral urbanization" (Caldeira 2017). These address, from different analytical angles or entry points and not as a coherent body of work, a certain problematic: the prevalence of "ordinary" urbanization processes in relatively poor neighbourhoods where local people are the primary agents of urbanism, organised across varying structures and scales, entangled with state actors in complex relationships. This is not to say that all these concepts engage with precisely the same processes, but they shed light on various aspects of widespread but noteasily-accounted-for urbanization processes and outcomes.

Based on ethnographic research, both Asef Bayat and AbdouMaliq Simone have introduced concepts addressing the role of individual and collective action without overarching organisation or mass mobilization, which nevertheless achieve cumulative gains. Bayat's (2000) concept of "quiet encroachment of the ordinary" brings into perspective often overlooked forms of resistance by subaltern groups, highlighting mundane acts that become contentious politics, and encroachments without clear leadership or organization. In a similar vein AbdouMaliq Simone's collaborative work on Jakarta (Simone and Fauzan 2012; Simone and Rao 2012) and on Yangon (Simone 2018) uses the notion of an "urban majority" to explore the articulations and workings of districts often located at the urban cores of large urban regions in the "Global South" and intermixing various ways of life, class backgrounds and functions (Simone 2018: 23). This heuristic concept is not derived from a quantitative measure of the urban population but refers to a heterogeneous group of people that constitutes itself through various practices and relationships. This idea of a heterogeneous population that is invisible in its ubiquity but which becomes visible at certain moments, for example as a voting body, is a powerful one.

Solomon Benjamin and James Holston reemphasise the importance of modalities of claims to land and show how various groups can manipulate specific power structures and legal instruments. They argue against simplistic understandings of power, politics, organisation and agency and emphasise instead entanglement, multiplicity and complexity. With "occupancy urbanism” Benjamin (2008) uses land as a conceptual entry point to look at highly politicised forms of urbanisms in India. He conceptualises cities as consisting of contested terrains constituted by multiple political spaces, all inscribed with complex local histories. With his concept he acknowledges a popular political consciousness that goes beyond passivity or 
exploitation and opens up a space of politics where poorer groups engage various levels of the state but remain autonomous from it, and where lower level government agents and bureaucracy are in turn deeply embedded in local community politics. In the context of the urbanization of the peripheries of Brazilian cities Holston (2008) uses the terms "insurgent citizenship" to question notions of illegality, its distinction from legality, the relationship between land occupation and law, and the entangled roles of individuals, civil society and the state in shaping urban areas. Illegality and contradictory regulations and practices, instability and bureaucratic irresolution are shown not just as norms, but as what makes Brazilian land occupation possible, and the means by which the urban poor and the subaltern make meaningful gains towards consolidation and tenure security.

Referring to case studies from São Paulo, Istanbul, Santiago de Chile, Delhi and Mexico City, Teresa Caldeira (2017) develops the notion of "peripheral urbanization". She uses the term "peripheral" as a metaphor to characterise pervasive urban spaces that are produced in a very different way than those of North Atlantic urbanisms. Peripheral urbanization thus represents a broad conceptualization addressing the heterogeneity of the poor and emergent urban formations, which are inherently unstable and contingent. Caldeira uses the notion of "transversality" to account for the way different actors engage with each other and with mainstream logics.

As this short review shows, there is already an important and inspiring body of work seeking to understand prevalent urban phenomena in "southern" urban contexts. These contributions conceptualize many aspects that we also recognized in our own case studies. Our comparative analysis drew together insights on a specific, multidimensional urbanization process which we identified in some of our case studies. In the following section, we explore "plotting urbanism" in Lagos, Istanbul and Shenzhen, demonstrating compelling similarities in the production of a dominant urbanization process across these very diverse urban contexts. We finally outline a more concise definition of plotting urbanism that might be relevant to other contexts and is therefore open to further discussion and revision.

\section{Lagos: Plotting as the ordinary process of urbanization}

Mr Ladipo ${ }^{\mathrm{vi}}$ grew up in the 1960s in rental accommodation in Mushin, a plotted area on the mainland of Lagos ${ }^{\mathrm{vii}}$, which was already fully developed. At the end of the 1960s his father 
bought a plot in Ijesha, around $5 \mathrm{~km}$ away, but the family remained in Mushin for another ten years while they worked to firm up the waterlogged land and build a couple of rooms in the new place. When they finally moved in, Ijesha was still "bush", but it gradually filled up and the area was fully developed by the 1990s. They had bought the plot from the Omo Onile viii in that area, the customary landowners, and have never had to pay any further money to them since. The first government intervention in Ijesha was when piped water was laid out in 1997. In 2012, Mr Ladipo's father was required by the state government to pay a Land Use Charge of around N12,000 per year (\$70 USD) - now his rubbish is collected. He has never sought out formal documentation as he knows that to do so means "paying twice", first to the Omo Onile (who might demand a repeat payment at current market price), and then to the government for expensive deeds (up to $30 \%$ of the land value). Mr Ladipo's father initially built a "Face-MeI-Face-You", a typical Lagos multifamily tenement building, renting out rooms and adding more floors as he could afford them. More recently he made the rooms self-contained with their own bathroom and hotplate, as he reasoned that people do not want to share facilities anymore. The family now owns several properties in the area and Mr Ladipo is a property agent. It is incredible to his father that properties in Ijesha are now selling for N15-20 million ( $\$ 85.000$ 115.000 USD).

As the example presented above shows, plotting urbanism enables rapid urban development in Lagos even though buildings on individual plots can take years if not decades to be finished. The typical Face-Me-I-Face-You buildings, such as the one that Mr Ladipo's family built, are types of concrete block tenements with four rooms mirrored over a central corridor with shared services at the end of each floor. They can be up to four storeys high and average 6 people per room, occupy up to $90 \%$ plot coverage but are always detached (Towry-Coker 2011). They are a ubiquitous idiom of Lagos life, filling neighbourhood after neighbourhood from the older central areas to the far reaches of the peripheries (Sawyer 2016).

This highly individualized urbanization process is tailored to personal circumstance, allowing people to become property owners and landlords without formalized financing (Lawanson $2012)^{\text {ix }}$. Likewise, people can access plots of land through customary landowners without having to resort to expensive and protracted bureaucratic procedures (Aina 1989a; DurandLasserve 2004; Lombard and Rakodi 2016). At the same time, plotting provides high-volumes of affordable rental housing for low-income tenants that form the majority of Lagos's residents. Yet this flexible and incremental urbanization process also has its downsides. First of all, it 
creates a huge social difference between the plot-owners and the tenants (Kumar 2011). Plotowners are invested in their property and established in the area; they might have saved and/or constructed for years, but becoming an owner significantly increased their social standing (Barnes 1986). The masses of tenants however have few rights, and as demand for rooms is so high, they are at the mercy of landlords who frequently increase rents, and often do not maintain their properties well (Oni and Durodola 2010). Yet being a tenant in a plotted area is a significant step up from living in even poorer and more precarious areas of popular urbanization with less solid buildings and little tenure security, and constitutes a viable option for a broad section of Lagos society, including students and civil servants.

Forged through more than a century of ambivalent governmental policies that officially condemned the development of plotted areas but did nothing to stop it, and constant political, economic and social instability, as well as contradictory land policies, plotting urbanism can be seen as the de facto model of urban development for the majority of Lagos (Sawyer 2016). However, there is little scholarship that looks at these vast areas as a meaningful object of study (Aina's work e.g. 1989b is a notable exception). Instead, urban research on Lagos tends to focus on the difficult living conditions, often conflating what are very heterogeneous urban areas with only their poorest material expressions, sometimes giving rise to a classic 'slum city' narrative (Agbola and Agunbiade 2009; Davis 2006). However, most urban spaces in Lagos, even for the elite, face significant infrastructural challenges. When even mansion owners have to organise their own sources of dependable power, water and sanitation, it is not access to publicly provided basic services that indicates wealth or poverty in Lagos, but the form and capacity of infrastructural services that the household can afford and access privately (Acey 2007). This need for nuanced differentiation also applies to material space: plotted areas can be highly differentiated both within and between neighbourhoods according to particular indicators such as access to transport links (and this differs with private car and public transport users) and proximity to markets (although being too close is often seen as less safe). Wealthier streets are quieter, with less street activity and plots are usually gated.

In general, the absence of building standard requirements and the lack of planning procedures, particularly in regard to densification and the provision of public space, has led to a low-quality building stock and an often degraded urban environment. However, this varies according to the relative wealth of the residents of a plot, street or area. ${ }^{\mathrm{x}}$ Thus, plotting urbanism produces a 
finely differentiated urban fabric where services can be closely tailored to available resources and the personal circumstances of tenants and owners and might vary from plot to plot. Recognising the viability of plotting urbanism and its affordability does not diminish the significant challenges faced daily by residents regarding the lack of publicly provided infrastructure. Thus, the strategies of plotting and individual service provision show both the potentials and the limitations of urban development for most sectors of the population almost entirely without government intervention (Sawyer 2016).

While Mr Ladipo's case illustrates well the pattern of plotting urbanism in Lagos, it is relatively unusual because he did not have to face any conflicts over land (Akinleye 2009; Ola Aluko 2012). In many situations, the dual land system of Lagos has created unresolved contradictions and resulted in widespread contestations over ownership and land title. This dual land regime has existed in Lagos since the imposition of British law through colonization in the mid $19^{\text {th }}$ Century (Hopkins 1980). The British colonial administration was never powerful enough to impose its land laws and planning regimes on Lagos entirely (Peil 1991). Much of its power was focused on the central Lagos Island and Apapa port areas. For the fast-growing areas of mainland Lagos, they leant heavily on existing structures of customary authority to maintain a minimal administration and turned a blind eye to their extensive influence over land divisions (Barnes 1986). In this way, Omo Onile have continued to exert their social and political power on the urbanization process and to maintain their authority and legitimacy through their claims to the land (Vaughan 2000).

These disparities were even further exacerbated through the formal division of mainland Lagos and the central districts ${ }^{\mathrm{xi}}$ between 1954-1967 as part of the creation of new regions in Nigeria that sought to more adequately represent and distribute power between the different ethnic groups (see Williams 1975). As the central district was already densely populated, the majority of growth largely occurred on the mainland, fuelled by colonial development, rural-urban migration, natural population growth and the urbanizing effects of the Second World War (Harris and Parnell 2012). Plotting flourished under these conditions, and the population more than tripled. What little formal development there was on the mainland at this time (most significantly the development of Ikeja) only served as a catalyst for the process.

A series of military coups in 1966 started three decades of profound economic, political and social instability that further inhibited the implementation of large planned urban developments 
or housing programs. In 1978 the national Land Use Act was introduced with the aim of establishing a unified policy on land and tenure that would resolve some of the contradictions between statutory land law and customary practices that had emerged since colonisation. However, plotting continued to be the de facto mode of urbanization for the mainland. The Land Use Act in fact served to compound the contradictions inherent in the dual land regime by even enshrining the paradox of dual root titles in its pages; it is written in such a way as to recognise customary landowners' claims of an inalienable right to land, at the same time it vests all urban land of Nigeria in the government (Ola Aluko 2012).

The bureaucratic procedures required by the Land Use Act are costly, protracted and prone to corruption and consequently very few plot-owners in Lagos sought formal titles. Today, notarised documents of transactions from customary authorities are the norm and offer comparable security to formal titles. However, customary concepts of land tenure and particularly the inheritance of land and property are not standardised and therefore are open to manipulation within and between both sides of the dual land regime, nurturing a culture of conflicts in plotted areas. Newspapers and online forums are full of stories of someone duped out of money in buying a plot, or who lost their plot to the Omo Onile with real or fraudulent claims to an indigenous right to land (Akinleye 2009). It is not uncommon to hear of someone having to pay for their plot a second time (or losing it entirely), a decade or more after first buying it, in order to settle a family member of the original seller who disputes the sale (Peil 1991). In these cases, both sides often have competing and contradictory documentation.

Today, plotting urbanism continues to transform Lagos, intensifying newly plotted areas at an ever increasing rate and pushing the frontiers of the urban region outwards beyond the boundary of Lagos State into neighbouring Ogun State. Once-peripheral plotted areas, which have now become central in the context of the rapidly growing urban region are increasingly desirable to a broader section of upwardly mobile people, and are now undergoing what might be understood as a second stage of plotting urbanism: As there is a rising demand for selfcontained apartments, Face-Me-I-Face-You buildings are demolished to make way for more expensive and better serviced houses. While wealthy plot-owners buy more land and redevelop their plots, poorer plot-owners are selling to small scale developers and moving out to the periphery to buy a new plot again, fuelling subsequent rounds of plotting (Sawyer 2016). Lower income tenants are particularly affected by these urban transformations, because they are likely to be forced further out. 
Since democracy returned to Nigeria in 1999 there has been a period of unprecedented stability in the leadership of Lagos State and a strong political will to promote a consistent urban development (Cheeseman and de Gramont 2017). However, urban planning has primarily focused on transportation infrastructure and continued to reinforce the central axis of development between the port, Ikeja, Victoria and Lagos Islands, now extended to the Lekki

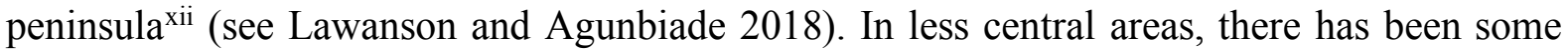
resurfacing of main connector roads, and the construction of drainage canals. In 2012, the governor of Lagos State implemented house numbering that included most plotted areas. Waste collection is near $90 \%$ for the entire city, and water levies and taxes are more efficiently collected (even if the service provision does not always follow). However, continuing their ambivalent approach to the plotted areas of Lagos, the state government is not directly involved in the process of plotting urbanism, and there is no push for further formalization. In the most recent master plans commissioned for the mainland area, most plotted areas are just designated as "mixed residential" with no explicit plans beyond the widening of exterior main roads (Dar Al-Handasah 2011).

In light of such ambiguities and contradictions, the future of plotting urbanism in Lagos remains open. The most pressing question for future urbanization is how to improve the legal situation for plot-owners and tenants without unbalancing the complex social, political and regulatory status quo that helps maintain the various advantages, such as flexibility and affordability, offered by this urbanization process.

\section{Istanbul: Plotting as consolidation and commodification of the gecekondu}

In the late 1980s Ahmet's family - originally from Turkey's Black Sea region - lived as tenants in Bağcılar, a rapidly transforming popular neighbourhood at the time. Ahmet bought a plot of illegally divided agricultural land in an emerging neighbourhood in the western outskirts of Istanbul. In 1991 he started construction without the necessary permits. He first constructed the first two floors employing handymen, but did not move in immediately. A year later, seeing that the neighbourhood was developing, he moved in permanently and continued to improve his building over the years, bribing the inspectors along the way. Currently his building stands five storeys tall. The first three floors are completed; he benefits from two businesses located 
at the ground floor. The last two floors with four apartments remain unfinished. He has now the resources to complete construction, but is waiting for legal uncertainties to be resolved before he is prepared to invest further. He estimates that he can charge 300 TRY (133 USD) monthly rent per apartment, which would be a decent source of income. ${ }^{\text {xii }}$

This story from Istanbul's vast urban peripheries exemplifies a phenomenon that goes beyond the notion of gecekondu, a form of low cost popular housing that initially emerged in the form of provisional shanties usually constructed on state-owned land. ${ }^{x i v}$ They were constructed and extended by their inhabitants and later went through phases of intensification and commodification. From the late 1940s onwards gecekondus provided much needed housing for rural-urban migrants, whose labour power was indispensable to the rapidly growing and industrializing economy of Istanbul. In our comparative project, we use the term "popular urbanization" to designate such areas constructed through the collective efforts of their inhabitants (see above).

In the decades that followed, thanks to clientelist networks and populist policies gecekondu areas transformed into dense urban neighbourhoods. Several laws sought to control and legalize gecekondu areas (known as gecekondu aflarl, "gecekondu amnesties"). The "Gecekondu Law" of 1966 was a landmark legislation in this process, because it recognized the existence of gecekondu areas and prescribed policies towards their containment and improvement (Tekeli 1992:68-69; Şenyapıl1 1998:311). In increasing tenure security, however, it also facilitated their commodification (Tekeli 1998:19). Quality of buildings and infrastructure visibly improved (ibid). In subsequent stages single storey gecekondus were replaced with multi storey reinforced concrete structures, alongside increasing entrenchment of informal land markets (Şenyapıl1 1992; Tekeli 1992: 91-92), while some gecekondus were even started with subsequent vertical extensions in mind - namely as the first storey of an extendable reinforced concrete structure. This process of vertical development was particularly striking during election periods, when authorities preferred to turn a blind eye to illegal expansions (Keyder 2005:126; Öncü 1988:47). The truly dramatic transformation of gecekondu areas occurred following a series of amnesty laws issued in the wake of the military coup of 1980, to legalize and regulate informal housing. Thus began a period of intensive plotting urbanism in Istanbul.

These amnesty laws, most significantly Law 2981 from 1984, issued amnesties for gecekondus and for unauthorized constructions on illegally subdivided agricultural lands. Beyond granting 
assurance against eviction, these amnesties also explicitly allowed the upzoning of many lowdensity gecekondu neighbourhoods (Ekinci 1998). This opened the floodgates of speculation (Duyar-Kienast 2005) and ushered in what Orhen Esen (2011) calls the "post-gecekondu" period. Gecekondu 'owners' were issued "title assignation documents" (tapu tahsis belgesi), essentially written promises for a legal title deed pending the execution of an "improvement plan" (ıslah imar planı) by the local authorities. Many gecekondu neighborhoods attained legality through this policy while some still remained in a limbo when, for various reasons, the municipalities did not implement an improvement plan. Throughout the 1990s and 2000s the central government kept on issuing new legislation to regulate unlawfully developed areas (for details see Tercan 2018).

The funding scheme and procedure of plotting urbanism depends largely on the locational advantages and the degree of tenure security of an area. In places with low effective demand plot owners rely on their individual resources and often are personally involved in the construction (Şenyapilı 1992). The vertical extension of the structure proceeds in different stages, as political and economic opportunities arise. In areas developed through self-financing the intensity of plotting tends to be limited, often blurring the lines of distinction between popular urbanization and plotting (for instance in the case of the construction of an additional floor for a family member). In higher demand areas with locational advantages plotting is based on yapsatçılık ('build-and-sell') (Duyar-Kienast 2005; Esen 2011; Işık and Pınarcıoğlu 2001; Ozdemir 1999): in this model, the individual owners strike deals with contractors. The plot (which would typically include the footprint of the built structure as well as outdoor spaces such as garden and courtyard) is redeveloped as an apartment building consisting of multiple floors. The owner and the contractor negotiate the share of flats to be handed over to the contractor. In parallel with the replacement of gecekondus by multi-storey buildings in the 1980s and 1990s, another form of plotting urbanism became prominent, whereby vast segments of peripheral districts of Istanbul (such as in Sultanbeyli, Altınşehir) were newly developed on illegally occupied or subdivided land (Işık and Pınarcıoğlu 2001; Öncü 1988; Yonder 1987). Here, rather than replacing an existing gecekondu, plotting entailed the construction of an apartment building directly on an empty plot, although often in an incremental way.

It is often argued that the development of informal land markets and the vertical redevelopment of gecekondus alleviated the negative effects of the neoliberal transition of the 1980s, which weakened redistributive state mechanisms, deepened socio-economic inequalities and 
increased labour precarity. By overlooking and in some cases even providing incentives for squatting through frequent amnesties, and later by providing the legal framework for plotting, the state effectively provided a source of compensation (Başlevent and Dayığlu 2005; Işık and Pınarcığlu 2001:82-83; Şenyapıl1 1998). These amnesties also instilled an ethics of homeownership and provided incentives for precarious social groups with potentially subversive political inclinations to develop into profit-seeking owner-citizens (see e.g. Erman 2001:987). Gecekondu residents actively lobbied in borough councils and participated in local politics often pragmatically switching party affiliations - so as to advance their property interests, and to retroactively legitimize unauthorised structures that they had already erected (Esen 2011:480). It is also during this time that the dominant representation of gecekondu people shifted from that of the "disadvantaged Other" to "the undeserving rich Other" (Erman 2001).

Increasing commercialisation of land development under plotting has most notoriously manifested itself in the fierce competition to capture wealth based on land rent, the entrenchment of rentiership, and exploitation of the poorest segments of the population (Bugra 1998; Işı and Pınarcığlu 2001:82 $)^{\mathrm{xv}}$. While some of the additional apartments are usually reserved for relatives getting married, the rest are sold or rented out. Particularly in prime locations the incentives for commodification can be very strong (Esen 2011). In their analysis of the commodification of informal housing and the increasing precariousness of the urban poor Işı and Pınarcıoğlu (2001) propose the term "rotating poverty," indicating situations in which certain segments of the urban poor, notably those who arrive first, are able to accumulate wealth at the expense of others. They use the case of Sultanbeyli, a hitherto peripheral rural area that was informally parcelized and rapidly settled through religious-communitarian networks, to demonstrate that those who participated in the earlier rounds of land occupation get the lion's share of land rents, and latecomers join the network as secondary buyers or tenants. The creation of wealth under this system is dependent on new members joining, and constant growth (ibid). In their detailed study of this pyramid-like scheme in Istanbul's Çeliktepe neighbourhood, Altınoluk and Enlil (2008) demonstrate a reverse correlation between the date of migration and possibilities for socio-economic upward mobility. In the 1990s and early 2000s the 'losers' of "rotating poverty" were often Kurdish citizens displaced as a result of the armed conflict in Southeast Turkey (ibid). Most recently a significant portion of the tenants are international migrants, including refugees from Syria. 
Another obvious downside of plotting is the poor environmental and material quality of the resultant urban areas. Under conditions of continuing growth in the real estate markets, and within the framework of a populist approach to unauthorized urbanization, most of what used to be low-density gecekondu neighbourhoods and peripheral agricultural lands urbanized rapidly in a rather haphazard fashion with low quality of construction. Even though improvement plans by local authorities sought to ameliorate the situation, their impacts were limited due to the de facto nature of development, and the on-going violation of building codes. Especially in high rent areas the owners built more floors than permitted, and encroached on common ground. There was practically no oversight on the quality of construction and the structural robustness of the buildings. In some extreme cases this resulted in tunnel-like streets with up to six storey buildings on both sides. Parks and other public areas are rare, and are often found in small corners left over from the construction flurry. Zeytinburnu, one of the earliest gecekondu settlements dating back to the late 1940s, which experienced heavy plotting in the 1980s and 1990s, is a prime example of this. In his meticulous documentation of Zeytinburnu, Akçay (1974:27) mentions various fruit and ornamental trees, behind which "gecekondus become invisible." The physical situation today, characterized by a dense reinforced concrete jungle is a far cry from that. Çetin ${ }^{\mathrm{xvi}}$, a shop owner in Zeytinburnu, was born and raised there. Recalling his childhood in the 1970s he spoke about houses with gardens and trees, and how he spent his time playing on the streets with his friends. In contrast, his children are stuck at home, as there is no space for them to play. "Now everywhere is full of cars...I want to send my daughters to swimming. But there is no place. Everywhere is full of houses. No empty space. They sit at home." Dramatic increase in density and population was in many places accompanied by anonymization of inter-personal relations (cf. Ayata 1989; Ozdemir 1999) and increase in petty crime (Yonucu 2008).

Plotting in Istanbul came to a near halt in the early 2000 s as a combined consequence of the severe economic crisis of 2001 and the ravaging 1999 earthquake, which claimed hundreds of lives and revealed the poor quality of construction. The Justice and Development Party (AKP), which came to power in the wake of the crisis initiated an "urban transformation" agenda and fortified the Turkish Housing Development Administration (TOKI) as its main agent (Karaman 2013a; b, 2014; Türkün 2014). This top-down model of renewal faced resistance from residents and did not have a significant impact. In this context, plotting has resurfaced in many former gecekondu areas (such as in Gaziosmanpaşa and Esenyurt). This latest wave of plotting is distinct from the previous ones in two respects: firstly, the material quality of construction is 
vastly superior; secondly, these new constructions usually follow zoning and building codes. Nonetheless, local power relations and negotiations are still crucial for the outcome.

These various examples show that the trajectories of plotting in Istanbul are quite diverse and resulting in uneven patterns of urbanization and urban landscapes. These are shaped by various factors, most notably tenure and land ownership status, proximity to centralities and connectivity to main transport axes (cf. Şenyapılı 1998:313, Işık and Pınarcıoğlu 2001:167, Esen 2011:485-486). While districts such as Zeytinburnu, and Bağcilar are heavily plotted today, some sections of Gaziosmanpaşa, Ümraniye, Sarıyer, Maltepe - among others maintain their low-rise gecekondu character.

Istanbul bears the heavy imprint of plotting in its urban fabric today. Thanks to plotting, precarious settlements have turned into dense robust neighborhoods, and peripheral agricultural lands have rapidly been urbanized. These settlements have provided housing for Istanbul's "urban majority", and have so far proven to be highly resistant to top-down schemes to redevelop them. Since the mid-2000s various urban renewal schemes have been attempted with limited success. In the meanwhile, plotted neighborhoods are slowly being upgraded (in some cases at higher densities) at the scale of individual buildings, and new plotted neighborhoods continue to emerge - albeit at smaller scales than in the 1980s and 1990s.

\section{Shenzhen: Plotting as a contradictory catalyst for rapid urbanization}

Looking from the 100th-floor of the Kingkey tower in the financial centre of Luohu one might discern in the midst of dozens of commercial skyscrapers a cluster of closely packed seven-toten storey buildings with thin lines of alleys and streets in between. This is Caiwuwei, whose high-density urban form with bustling street life strongly contrasts with its well-organized and controlled surroundings filled with skyscrapers, shopping malls, office blocks and condominium towers. One can also stroll around the grungy and narrow alleys of places like Hubeicun, Sungang, and Baishizhou, with some overhead blending of electric and internet wires, water dripping from air-conditioners, and sewer lines under the feet. These are all urbanized villages, or chengzhongcun ("village-in-the-city"), which are commonly represented as composed of "hand-shaking buildings", or as building spaces leaving open only "a line of the sky" because of the countless narrow alleys running between the buildings. In fact, these seemingly haphazardly constructed settlements formed the very basis of the growth of the 
contemporary urban region of Shenzhen, counting 12 million inhabitants in 2016 (Shenzhen Statistics Bureau 2017).

In 1980, when Dengxiaoping declared Shenzhen as a Special Economic District (SED), it was a rural area located in Bao'an county between Hong Kong and Dongguan, with fields surrounding the small town of Shenzhen. Village collectives owned the land and exercised functions of rural government inherited from the People's Communes. The central government established a SED of 327 square kilometres in the southern part of Bao'an county at the border with Hong Kong. As a forerunner of the future national economic policy, the administrative status of Shenzhen was reshuffled from a county (xian) to a city (shi) ${ }^{x v i i}$. In 1988 the city government was directly subordinated to the central government in terms of economic planning. However, this administrative reshuffling created a legal twilight zone in which rural and city government systems co-existed and interwove, which soon produced a whole series of contradictions and conflicts.

The first problem emerged from the fact that the large majority of the land belonged to the village collectives, while the city only owned three square kilometres of land surrounding the former Shenzhen town (SUPLAB 1999). Since the land rights of the villages were strongly upheld in the national law, the city government had to acquire farmland with compensation for the village collectives and to offer jobs to the affected villagers. In order to push urban development, the government introduced a new policy of land exchange: it acquired farmland while granting the village collectives the right to develop a portion of their own farmland into industrial and commercial zones ("non-agricultural land"), thereby enabling the creation of jobs and additional income for villagers (Zhang et al 2003). However, this pragmatic solution in turn triggered subsequent contradictions, because it created an institutional dualism in regard to land development. On the one hand land owned by the state was delegated to the city of Shenzhen; this land was defined as "urban" land and could be used for housing, industrial and commercial uses. On the other hand the land of the village collectives remained designated as "rural". This dual land policy led to a contradictory urban development process: while the city government started to develop the "urban" land according to master plans, it created at the same time the institutional framework for the village collectives to participate in the urbanization process and to develop also their "rural" land. Throughout the 1980s, villagers were encouraged to construct new one-to-two storey concrete buildings with courtyards, which soon sparked the massive expansion of the settlement areas of the villages. 
As a consequence, the village collectives continued to own and manage their inherited land, whilst the city government enacted new building codes and regulations for this "rural" land, but relied on the village leaders to implement these codes and regulations (Wang et al 2009). A policy of red lining was applied to demarcate village boundaries and to contain their expansion. However, during the late 1980s, villages started to build houses on farmland outside the red lines, but only on a modest scale (ibid). This practice, which villagers understood to be conforming to their traditional rights, was deemed illegal by the city government. Thus, the coevolution and overlapping of the divided spaces of "rural" and "urban" government generated a legal twilight zone (Ho 2001), and led to the development of the spatial form of urbanizing villages, a kind of rural-urban interface emerging alongside the expanding urban areas controlled by the city of Shenzhen. In this way, plotting urbanism started in Shenzhen.

During the 1980s, Shenzhen legalized the transfer of land-use rights through several rounds of amendments, thereby accelerating urban development (Ng and Tang 2004). In 1988, a further amendment to the Constitution was approved by the National People's Congress, allowing local governments to lease state-owned land to private developers (see Lin and Ho, 2005). This fuelled the widespread transformation of farmland into urban development zones throughout the 1990s, widely known as "land fever" (Cartier 2001). Immediately after this reform the Shenzhen government accelerated the pace and scale of urban development and eventually deprived many villagers of their landownership rights. In 1989 it imposed an ambitious, forceful and systematised urbanization strategy within the SED. This included a large-scale program of farmland acquisition, which aimed at increasing the land reserve of the government for urban expansion, and at the same time sought to remove administrative barriers that had emerged previously from piecemeal land acquisition. To do so, it reclassified all rural land to the status of state owned land ("administrative-allocated land"), on which village collectives could hold land-use rights as leaseholders (SUPB 2005). According to the constitution, the procedure to change rural land into state land would have necessitated land expropriations and compensations; instead, the practice the Shenzhen government adopted was to simply reclassify all collective landownership into state-owned land. Additionally, the Shenzhen government had to integrate the existing rural collective system through a policy of "rural urbanization" for all the villages in the SED ${ }^{\mathrm{xviii}}$, which also meant to grant the status of urban residence (hukou, see below) to the villagers. This administrative restructuring also included the transformation of rural cooperatives into (modern) shareholding companies. 
The purpose of these reforms was to abandon the dualistic land regime and to eliminate the institutional barriers between rural and urban systems, and to impose urban administration and planning standards across the entire village land. The then Party leaders promoted these changes as part of a modernisation of Shenzhen through integrating the rural into an urban society (chengxiang yitihua) (Shenzhen Museum 1999:383). However, this strategy triggered widespread discontent amongst the villagers who responded to this top-down policy with a massive wave of plotting through illegal land conversion and building construction. ${ }^{x i x}$

Plotting thus became a form of resistance strategy through which villagers opposed government policies by materially occupying land, thus defending their land rights on the ground. This has been a well-known practice of peasants in China, called "zhongfang baodi", meaning "planting houses, defending land" (Nanfang Zhoumo 2014).

Since the late 1980s, plotting also took place in the outer zone beyond the SED border, across a vast area of about 1,700 square kilometres located in Bao'an county. While the chengzhongcun inside the SED gradually developed into densely-built urban areas, the urbanization of the villages beyond the SED border (er xian guan), for example in Shiyan, Longgang and Shajing, emerged as a result of the spill-over of industrial development from the SED. The outer zone thus developed into a kind of assorted and fragmented urban landscape, because the agricultural plots around traditional villages were variously subdivided into industrial districts, multi-storied buildings, gated housing estates, markets, government buildings and public facilities, somehow connected by the ever-expanding highways and metro lines (UPDIS and UESPKU 1998). Plotting happened in the outer zone under different conditions than in the SED (see Ma and Blackwell 2017), basically because of various conflicts emerging amongst the different actors involved in the development and regulation of the land, including the county government, the town governments, the village collectives, the village households and the city government. In order to accelerate land development, the city government of Shenzhen made several attempts to gain control over the entire territory outside of the SED. First, in 1993 it changed the territorial system so that the city government could unify and control the planning system within the whole territory of Shenzhen. Second, in 2002, it started to convert the rural village system and to integrate the collective landownership into the urban administration, a measure that affected a much larger territory than the previous administrative reorganization of the SED ${ }^{\mathrm{xx}}$. However, even as these changes were being pursued, local officials were informally issuing housing permits, while village cadres and 
villagers illegally subdivided farmland for various purposes and made profits from the sale of unofficial land leases, which finally contributed to the failure of the implementation of the new land policies (UPDIS and UESPKU 1998). These changes created conflicts over land interests, and eventually led to widespread resistance by villagers through plotting of land, especially at some prime locations. Many villagers hesitated to register their properties or to sign an agreement of new landownership, because they would have acquired only land-use rights for 70 years and permanently lost their landownership rights. A new burst of plotting emerged after 1999 when the government announced new regulations against illegal construction. In 2001, a new policy of legalisation was introduced for some illegal structures, which fuelled another round of plotting because some villagers perceived this as an opportunity to maximise the floor space eligible for legalisation.

To summarize, the recurrent emergence of plotting urbanism in Shenzhen has been driven by various attempts of the city government to extend control over the territory: 1) Whenever the government sought to overcome resistances of the villages through institutional changes, it resulted in new contradictions and ambiguities (O'Donnell 2017; O'Donnell et al 2017), and spurred further rounds of plotting. 2) For each round of land acquisition, the government had to cede a portion of the land to the villages, and thus plotting expanded further. 3) Another contradiction arose when the reclassification of land rights deprived villagers of their inheritable land. But even after shareholding companies and villagers lost their land titles, they continued to act as de facto landowners (Pu Hao et al 2012; Y Lai et al 2017; Wang et al 2009; L. Zhang et al 2003).

Thus, through plotting, villages could generate and sustain increasing rents and market values, even if most buildings were without official documentation. It is telling that plotting urbanism has been officially considered as "villages boycotting" the policies of the government. ${ }^{\mathrm{xxi}}$ As addressed by Bach (2010), although these villages lost their rural status, they retained the discursive and spatial imprint of villages in the city. ${ }^{x x i i}$ As a result, plotting urbanism has left a fundamental mark on the urbanization of Shenzhen: it enabled the clustering of small and medium sized industrial companies, and the construction of various infrastructures and facilities within village areas. It also produced a huge rental housing market: about 38 percent of Shenzhen's total residential floor space in 2009 was located in plotted areas (Pu Hao 2015). In short, the villages developed into a kind of mixed neighbourhoods for a rapidly growing 
heterogeneous population coming from different provinces. They offered a great range of concrete possibilities for migrants to organise their everyday lives, establish small businesses, and maintain their relationships with their hometowns.

Plotting urbanism in Shenzhen thus had a twofold effect: it supported massive and fast urbanization, and it fostered the creation of a new rentier class with the transformation of village collectives into real estate shareholding companies. As addressed by Bach $(2010,433)$, "Shenzhen's villages became as much an experiment with the market as the [special economic] zone itself'. This process of commodification also profoundly changed the social relationships between local villagers and their tenants. The key to understanding this strongly asymmetrical and unequal social relationship is the Chinese hukou system, which continued to impose a dual structure of rural and urban household registration after 1978, tying a large part of the rural population to their original hometowns for education, health service and social service, thereby also affecting their social status in urban societies (P. Hao et al 2013; Wang et al 2009, 2010; L. Zhang et al 2003; Li Zhang 2005). The hukou system represents the control of the state over internal migration, and in the course of rapid urbanization it also enables the state to limit ruralurban migration and to avoid additional burdens on welfare and social facilities for cities (Buckingham and Chan 2018; Chan 1996, 2009; Fan 1999). The Shenzhen government used the hukou system also as a bargaining instrument by offering urban hukou to local villagers in return for their landownership rights. Nevertheless, many villagers have been reluctant to give up their land rights for urban status. Also many of those migrants to whom the city of Shenzhen had offered the hukou expressed the same reluctance because they wanted to secure their investments in houses or businesses in their urbanising hometowns where they expected to return someday. ${ }^{\text {xiii }}$ Due to their rural hukou, many migrants have not settled down but continued to migrate to different places. However, these migrants are highly heterogeneous: while there are a great number of floating "rural migrant workers", there are also small traders, shop owners, street venders, self-employed, half-employed or daily-employed, or students, living and working in chengzhongcun.

The most recent round of plotting - though relatively limited in scope - started as a reaction to a new urban renewal policy announced by the city government of Shenzhen in 2004, based on "demolition and redevelopment" of chengzhongcun, an approach that has also been launched in many other Chinese cities (Zhang, 2005, 225). In the following years, urban renewal became a new strategy of economic growth and a proposed solution to land shortage. While the new 
system enabled "market" forces to produce new urban spaces through various incentives for developers (Hin and Xin 2011), it was also strongly motivated by the political agenda to dismantle the large amount of illegal chengzhongcun.

Despite the fact that government and media discourses represented chengzhongcun as problematic, many scholars have acknowledged the positive roles of urbanised villages in the Chinese urbanization process and in turn highlighted the negative social impacts of redevelopment projects (Pu Hao et al 2012; Song et al 2008; Wang et al 2010; Li Zhang 2005). There are still a large number of chengzhongcun in Shenzhen, but urban renewal has become the new dominant model of urbanization.

\section{Plotting urbanism as a new concept of urbanization}

The concept of plotting urbanism allows an understanding of the production of certain lowincome and highly dynamic neighbourhoods from a new angle. It results from the comparison of an unusual combination of case studies and captures a multidimensional urbanization process that has not been conceptualized so far. As the discussion of the three case studies reveals, plotting urbanism occurs in very different socio-economic contexts, is underpinned by various political constellations and follows quite distinct trajectories. What keeps these examples together? How can plotting be identified as a distinct process of urbanization? What are its core characteristics? Despite obvious differences and idiosyncrasies, these examples show remarkable commonalities, that can be summarized in four main points: First, plotting unfolds in a piecemeal and incremental way, plot by plot, either escaping or bypassing - at least partly - comprehensive planning efforts. Second, plotting expresses and materializes a specific relationship to the land, which is based on various ambiguities that are temporarily stabilized by some sort of a territorial compromise between landowners, plot-owners and state actors. This compromise is often based on the conflict-ridden overlapping of formal or informal regimes of territorial regulation, land tenure and property rights, and can also include traditional or customary rules. Third, plotting generally includes the commodification of housing, and in some cases also highly speculative land markets. It thus rests upon the exploitation and realization of the rent gap generated through processes of urbanization and/or urban intensification. Fourth, the distinction between property-owners (as rentiers) and their tenants, who often live in the same neighbourhood or even the same building, creates specific social relationships and even conflicts in everyday life. However, as our examples clearly show, the power relations between divergent interests change constantly, eventually shifting the 
dynamics that led to the status quo of plotting in the first place, dismantling the territorial compromise and nudging plotting urbanism into a different, subsequent process of urbanization.

\section{1) Plotting is a piecemeal and incremental process of urban development}

Plotting unfolds incrementally either as new construction at the urban peripheries or intensification of existing settlements. The transformation of plots by their owners, often through the incremental addition of new rooms, floors or houses, sometimes also by the replacement of entire buildings, form the material basis of the process. This piecemeal aspect marks a fundamental difference from the production of mass housing, the development of condominiums, as well as from the construction of 'regular' individual homes; these are usually based on comprehensive housing policies and state spatial strategies, follow planning regulations to a certain degree, and often apply standardized layouts and floor plans. While plotting might also be marked by a more or less standard typology, as in the case of the FaceMe-I-Face-You buildings in Lagos, the yapsat apartment building typology in Istanbul or the housing towers in Shenzhen, its concrete realization also depends strongly on various circumstantial constellations and individual decisions, which can create a wide variety of urban outcomes. Everyday experience in such neighbourhoods may vary considerably depending on the particular social situation: the often cramped and crowded plotted neighbourhoods can offer space for a wide range of small businesses and activities on the basement or ground floors, resulting in a lively street life. Plotted areas have a great capacity to adapt easily to changing social and economic conditions, with the potential for developing more robust urban qualities over time. Simone's (2014) analysis of everyday experiences in mixed districts of central Jakarta illustrate well the everyday difficulties and qualities experienced in such neighbourhoods.

However, the predominance of a speculative logic and a lack of comprehensive planning also lead to ambivalent urban outcomes. As actors seek to maximize the exploitation of individual plots, the result is often a lack of public spaces and utilities: dense neighbourhoods with strained infrastructure, limited outdoor spaces and inconvenient layouts are therefore a common feature of plotting. When up to seven story buildings have been constructed on the original plots, eliminating all green space, as in Istanbul's former gecekondu neighbourhoods, the streets end up having a claustrophobic, tunnel like quality. Many chengzhongcun in Shenzhen present extreme examples of residential density, with building facades almost 
touching each other while sparing only "a line of the sky". Plotting in Lagos unfolds even in the complete absence of any formal planning, and often with very low quality of construction, as frequent building collapses testify.

The piecemeal and individualistic aspects of plotting do not imply that the state or collective agencies are absent, though. While in Lagos even the procurement of basic infrastructural services is individualised, in Istanbul and Shenzhen state institutions intervened - with varying effectiveness - to contain, regulate, and even provoke or encourage plotting. Besides state actors, elements of collective organizing, and community ties also determine outcomes to a certain extent. Individual actors are also constrained by the available construction know-how and technology, and are strongly influenced by dominant models of houses and apartment layouts, and of course follow profitability calculations. Thus, thousands of individual actors might end up following similar trajectories as a result of collaboration, imitation, adaptation, path dependencies and varying constraints imposed by state actors. Entire neighbourhoods with distinctive features, facilities and small businesses emerge without master plans but by constant testing, negotiating and muddling through.

\section{2) Plotting emerges as the result of a specific territorial compromise}

Plotting emerges under specific conditions of regulatory ambiguity and recurrent negotiations. We refer to this situation as a "territorial compromise", between a combination of traditional property rights, hard-fought collective claims, as well as formalised, 'legal' rules as backed by state institutions. Such territorial compromises often emerge from unresolved conflicts over land and tenure, which potentially impede further development, but also offer opportunities for individual gain for a variety of actors involved, such as landowners, plot-owners, customary authorities, state officials, and small-scale developers. Because it constitutes a significant investment in land, and competing rights are difficult to resolve, plotting might be an important strategy for asserting claims over land and strengthening negotiating power. Therefore, village collectives, community groups, social movements, religious communities but also mafia-like organizations could wield major influence, depending on their level of organisation and the political resources they are able to mobilize. In this context, informality and illegality represent an important element in the dispute over land, and a means to impose "facts on the ground". However, this kind of territorial compromise is usually not stable, but might be challenged or renegotiated by any of the involved actors. 
In Istanbul, the conflicts and negotiations underlying plotting urbanism evolved as part of the longstanding process of consolidation of popular neighbourhoods, developing from squatting and tolerated illegality at the beginning to a kind of negotiated and regulated illegality and finally towards regularization in the final stages of the process. The regulatory uncertainties found their expression in continuous negotiations over claims to land and development rights, and the frequent amnesties of 'illegal' settlements finally led to gradual regularization of informal areas. In Shenzhen, plotting was based on an entrenched ambiguity concerning the control over the land and its designation as "rural" or "urban" land, manifesting itself in the enduring conflict among village collectives, villagers and the city government. In this context, plotting became the main process driving land transformation and housing production. The village collectives were able to navigate the constant changes to the territorial governing system and challenge the government's "land grab" in the course of Shenzhen's urbanization. Plotting was thus a means of claiming space and of increasing the negotiating power of the villagers, and it was a very effective strategy of resistance to the imposition of state control over village land. As a consequence, villagers managed to play a key role in the urbanization process itself, and finally became co-owners of shareholding companies and thus developers in their own. In Lagos, plotting is based on the duality of the formal and the customary land regime. On the one hand, this duality creates a contradiction between plot-owners and customary landowners, often wealthy families, who use (and often misuse) their claims on the land. On the other hand, it also functions as a driving force for the urban process, making land available on a plot by plot basis and thus allowing to provide high-volumes of affordable rental housing for low-income tenants. In a situation, where people have learned to expect little from state agencies as well as from customary authorities, this also resulted in extensive self-provisioning of urban services. This particular status quo has developed over many decades, in which plotting has become the dominant process of urbanization in Lagos.

\section{3) Plotting is based on the commodification of housing and the exploitation of the rent gap}

Various forms of commodification play a key role in the process of plotting. In contrast to popular urbanization, social housing, or certain forms of cooperative housing, in which the use value of housing predominates, plotting is an important instrument for the generation and extraction of exchange value from the land and thus for realizing the potential rent gap in the area. In the context of the gentrification debate Neil Smith (1996) defined "rent gap" as the difference between the amount of rent the current landowner extracts from a plot, and the potential ground rent that could be realized if the land were redeveloped to reach its maximal 
profit. Adapting this definition for our purposes, we focus on intensification and marketization of land use (see also Ozdemir 1999) - rather than on realizing the full potential of the rent gap through redevelopment or refurbishment. This revised definition also follows Shatkin's (2017) understanding of the rent gap in his comparative analysis of urban real estate mega projects in Asia. He proposes to decontextualize the concept of rent gap from the concept of gentrification and its Euro-American settings in order to make it applicable to a broader set of situations. $\mathrm{He}$ shows how the extraction of emergent rent gaps is not only a source of profit for corporations but also a means for states to consolidate and expand their power. As he observes, "the prevalence of dualistic land rights regimes constrains the commodification of urban space and the realization of land rents" (ibid: 28). As the case of plotting urbanism shows, the rent gap could indeed be generated through the stabilization of land regulations and formalization of land titles which might turn dwelling units with low exchange value into formally recognized assets and instruments for wealth creation (see e.g. de Soto 2000 on "dead capital"). In contrast to real estate mega projects, individual property owners and small-scale contractors, and not the state and large corporations are the primary beneficiaries of plotting. And in contrast to gentrification, commodification by plotting does not necessarily result in large scale displacement of residents and small businesses. Even though displacement of original tenants is possible due to increasing rents (see Ozdemir 1999), the outcome of plotting is mostly intensification and/or densification and thus results in a net increase of housing for low-income people.

\section{4) Plotting involves specific tenant-owner relationships}

The relationship between landlords/plot-owners and tenants shapes the social and political situation in plotted neighbourhoods in significant ways. In offering newcomers and immigrants (relatively) affordable housing, plot-owners have the opportunity to maximise revenues and accumulate over time. Owning a plot of land, or ultimately a share in a real estate company, can significantly increase social standing and can be vital to participating in local politics and decision making. The particularities of the tenant-owner relationship depend on the degree of densification, the level of immigration, and the specific property rights in place. In the case of Lagos, property ownership is on the basis of the entire building and the plot-owners sometimes live in the same building, until they accumulate enough savings to relocate to newly constructed buildings with better amenities. This example approximates a certain tenement logic as illustrated by Huchzermeyer's (2011) study of contemporary tenement formations in Nairobi. In the case of Istanbul, a strong condominium law, which confers ownership rights based on 
individual apartments, undermined grounds for a full-fledged tenement concept: in a single apartment building one could find the original plot-owners, new homeowners who have purchased units from the original owners or the contractor, and tenants. Especially in high demand areas former gecekondu owners were able to accumulate some wealth often at the expense of newly arrived migrants who could find housing only as tenants. In Shenzhen, the income from rents has been a major tool of wealth generation as villages transformed from agricultural collectives into 'property empires.' While the original villagers usually remain in the area, they inhabit separate and higher-quality housing. In recent years, the shareholding companies owned by the villagers effectively sold their plots to great profit, ending the process of plotting and giving way to large scale urban renewal projects which eventually lead to significant upgrading as well as displacement.

\section{Conclusion}

What we detected in our research and propose to conceptualize under the term "plotting urbanism" is a process that goes beyond "urban informality" or specific "Southern" forms of urbanization. Plotting offers a pragmatic and viable solution to the concrete problem of urban development in specific contexts, where affordable housing is missing, access to land is restricted, and territorial regulations are unclear, ambivalent and/or contested. Even if highly specific circumstances and factors have led to plotting in our case studies, the cumulative effects of the individual plot-by-plot strategy have demonstrated astonishing transformative capacities in relatively short periods of time: plotting was the main urbanization process at a given time in each of the cities we analysed, and it allowed the rapid and massive urban growth in a crucial moment of urban development.

Plotting urbanism has thus not to be understood as a static and stable urban configuration but as a highly dynamic process with a specific temporality: it transforms urban territories, but the dynamics of the process itself are also in constant change. Plotting originates from a set of conditions, establishes a new status quo that produces a sometimes unstable socio-spatial configuration, and it might further transform into a very different urban process. The specific socio-historic conditions of each urban context may lead to very different material outcomes and trajectories of plotting: in Lagos, plotting is the almost generic form of urban development, that unfolded over decades and today constitutes the bulk of the built environment, whereas in Istanbul the urban process started usually with popular urbanization, which was based on solidarity and social networks, and over decades turned into plotting, in which the commercial 
logic dominates. Also in Shenzhen, plotting can be understood as a specific historical phase of the urban process, which formed the basis for the development of an entire new urban region, and now is gradually fading away in the face of larger scale state driven urban renewal. As speculative logics become stronger, conditions for the end of plotting as we defined it here or a transition to scaled-up versions of it with the involvement of more powerful actors become evident.

As a result of our comparative analysis we finally arrived at "plotting urbanism" as a concept that we think might enrich the vocabulary of urbanization. We believe this concept could be fruitfully applied to other places and could thus help to conceptualize hitherto unrecognized urbanization processes. Soliman (1996)'s account of "semi-formal housing developments" in Alexandria features many elements of plotting. In Jakarta, plotting could be applied to the question of urbanized Kampungs, which were analysed in great detail, among others, by Simone (2014). These areas are currently experiencing another dramatic round of rapid transformation into condo-developments (Leitner and Sheppard 2018), a process that shows striking similarities to the case of Shenzhen. The process of urbanization through the development of "census towns" in Delhi and other Indian urban regions also display many aspects of plotting ${ }^{\mathrm{xxiv}}$ - an observation that would merit further investigation (see e.g. Zerah and Denis 2017).

By conceptualising plotting urbanism as a prevalent and ordinary process of urbanization and by locating it in its historic and territorial contexts, we might also begin to formulate more focussed policy-relevant questions, and explore the modes and procedures of housing production that could enable the great urban qualities of plotting - such as adaptability of the built structure to various uses, access to relatively affordable land and housing and rapid delivery of housing at a large scale - while limiting its drawbacks such as exploitative ownertenant relationships, low quality of construction and infrastructure, and lack of common amenities and public spaces.

\section{Acknowledgements}

This article resulted from the collaborative research project "Patterns and Pathways of Planetary Urbanization in Comparative Perspective" carried out in the framework of Future Cities Laboratory (FCL), Singapore-ETH Centre and the Chair of Sociology, Department of 
Architecture at ETH Z€urich. Earlier versions of this paper were presented at the 2013 AAG conference in Los Angeles and the 2015 RC21 conference in Urbino. We thank all our colleagues from the Future Cities Laboratory (FCL), Singapore-ETH Centre for their support, advice and inspiration. We express our special thanks to the project team members Naomi Hanakata, Pascal Kallenberger, Anne Kockelkorn, Monika Streule and Rob Sullivan who contributed substantially to the development of the concepts of urbanisation discussed here. Furthermore, we would like to thank Jennifer Robinson and AbdouMaliq Simone for their thorough, illuminating and critical comments, as well as Orhan Esen for his insights on the case of Istanbul. We are also grateful to all researchers and urbanists who kindly participated in our mapping workshops and generously shared their knowledge in the earlier stages of the project. All authors contributed equally to this paper. All errors and omissions remain the responsibility of the authors.

\section{Bibliography}

Acey C (2007) Space vs. race: a historical exploration of spatial injustice and unequal access to water in Lagos, Nigeria. Crit Plan 14(Summer):49-69

Agbola T and Agunbiade E M (2009) Urbanization, slum development and security of tenure: the challenges of meeting millennium development Goal 7 in metropolitan Lagos, Nigeria. In A de Sherbiniin, A Rahman, A Barbieri, J C Fotso, and Y Zhu (eds) Urban PopulationDevelopment-Environment Dynamics in the Developing World: Case Studies and Lessons Learned (pp 77-106). Paris: CICRED

Aina T A (1989a) Popular settlements in metropolitan Lagos, Nigeria: a socio-economic and structural survey of the habitat of the urban poor. Third World Planning Review 11(4):393

Aina T A (1989b) "Many routes enter the market place": housing submarkets for the urban poor in Metropolitan Lagos, Nigeria. Environment and Urbanization 1(2):38-49

Akçay F (1974) Zeytinburnu: gerçek yönleriyle bir gecekondu kenti [Zeytinburnu: a gecekondu town in its reality]. Istanbul: Akçay Yayınları

Akinleye R T (2009) Contesting for space in an urban centre: the Omo Onile Syndrome in Lagos. In Locatelli F and Nugent P (eds) African cities: competing claims on urban spaces (pp 109-134). Leiden ; Boston: Brill

Altınok E and Enlil Z M (2008) " Yasadışı yapılaşmış alanlarda kazananlar ve kaybedenler: bir "sona kalan dona kalır" öyküsü [Winners and losers in illegally developed areas: a story of "first come first served" ". paper presented at Dünya Şehircilik Günü 32. Kolokyumu [32th World Urbanism Day Colloquium] Istanbul

Aluko O (2012) Spatial scales and measurement of housing values in Nigeria: the case of 
Metropolitan Lagos. Ethiopian Journal of Environmental Studies and Management 4(4):2738

Aluko Ola (2012) The effects of land use act on sustainable housing provision in Nigeria: the Lagos state experience. Journal of Sustainable Development 5(1):114 - 122

Ayata S (1989) Toplumsal çevre olarak gecekondu ve apartman [Gecekondu and apartment as social environments]. Toplum ve Bilim 46/47:101-127

Bach J (2010) "They come in peasants and leave citizens": urban villages and the making of Shenzhen, china. Cultural Anthropology 25(3):421-458

Barnes S T (1986) Patrons and power: creating a political community in metropolitan Lagos. Bloomington: Indiana University Press in association with the International African Institute, London

Başlevent C and Dayığlu M (2005) The effect of squatter housing on income distribution in urban Turkey. Urban Studies 42(1):31-45

Bayat A (2000) From dangerous classes' to quiet rebels' politics of the urban subaltern in the global south. International Sociology 15(3):533-557

Benjamin S (2008) Occupancy urbanism: radicalizing politics and economy beyond policy and programs. International Journal of Urban and Regional Research 32(3):719-729

Brenner N and Schmid C (2011) Planetary Urbanization. In Gandy M (ed) Urban Constellations (pp 11-13). JOVIS Verlag

Brenner N and Schmid C (2015) Towards a new epistemology of the urban? City 19(2-3):151182

Buckingham W and Chan K W (2018) One city, two systems: chengzhongcun in China's urban system. Journal of Contemporary China 27(112):584-595

Bugra A (1998) The immoral economy of housing in Turkey. International Journal of Urban and Regional Research 22(2):303-307

Caldeira T P (2017) Peripheral urbanization: autoconstruction, transversal logics, and politics in cities of the global south. Environment and Planning D: Society and Space 35(1):3-20

Cartier C (2001) "Zone fever", the arable land debate, and real estate speculation: China's evolving land use regime and its geographical contradictions. Journal of Contemporary China 10(28):445-469

Chan K W (1996) Post-Mao China: a two-class urban society in the making. International Journal of Urban and Regional Research 20(1):134-150

Chan K W (2009) The Chinese Hukou System at 50. Eurasian Geography and Economics 50(2):197-221 
Cheeseman N and de Gramont D (2017) Managing a mega-city: learning the lessons from Lagos. Oxford Review of Economic Policy 33(3):457-477

Dar Al-Handasah (2011) "Stage 3 Report - Final Model City Plan". Lagos, Nigeria

Davis M (2006) Planet of slums. Verso

Durand-Lasserve A (2004) "Land for Housing the Poor in African Cities. Are the NeoCustomary Processes an Effective Alternative to Formal Systems?". Presentation. Centre National de la Recherche Scientifique: PRUD-DFID

Duyar-Kienast U (2005) The formation of gecekondu settlements in Turkey: the case of Ankara. Münster: LIT

Ekinci O (1998) Kaçak yapılaşma ve arazi spekülasyonu [Unauthorised construction and land speculation]. In Y Sey and Ö Derya (eds) 75 Yılda Değişen Kent ve Mimarlık [Changing architecture and the city during 75 years] (pp 191-207). Istanbul: Tarih Vakfi

Erman T (2001) The politics of squatter (gecekondu) studies in Turkey: the changing representations of rural migrants in the academic discourse. Urban Studies 38(7):983-1002

Esen O (2011) İstanbul'dan öğrenmek [Learning from Istanbul] In Y Köse and A Dağlı (eds) istanbul: Imparatorluk Başkentinden Megakente [Istanbul: from imperial capital to megacity] (pp 461-494). isstanbul: Kitap Yayınevi

Fan C C (1999) Migration in a socialist transitional economy: heterogeneity, socioeconomic and spatial characteristics of migrants in China and Guangdong province. International Migration Review 33(4):954-987

Gilbert A (1983) The tenants of self-help housing: choice and constraint in the housing markets of less developed countries. Development and Change 14(3):449-477

Hao P, Hooimeijer P, Sliuzas R and Geertman S (2013) What drives the spatial development of urban villages in China? Urban Studies 50(16):3394-3411

Hao P, Geertman S, Hooimeijer P and Sliuzas R (2012) The land-use diversity in urban villages in Shenzhen. Environment and Planning A 44(11):2742-2764

Hao P (2015) The effects of residential patterns and chengzhongcun housing on segregation in Shenzhen. Eurasian Geography and Economics 56(3):308-330

Harris R and Parnell S (2012) The turning point in urban policy for British colonial Africa 1939-1945. In Demissie F (ed) Colonial architecture and urbanism in Africa: intertwined and contested histories (pp 127-152). Farnham, Surrey, England; Burlington, VT: Ashgate

Hin L L and Xin L (2011) Redevelopment of urban villages in Shenzhen, China - An analysis of power relations and urban coalitions. Habitat International 35(3):426-434 
Ho P (2001) Who owns China's land? Policies, property rights and deliberate institutional ambiguity. The China Quarterly 166:394-421

Holston J (2008) Insurgent Citizenship: Disjunctions Of Democracy And Modernity In Brazil. Princeton: Princeton University Press

Hopkins A G (1980) Property Rights and Empire Building: Britain's Annexation of Lagos, 1861. The Journal of Economic History 40(4):777-798

Huchzermeyer M (2011) Tenement cities: from 19th century Berlin to 21st century Nairobi. Africa World Press London

Işık O and Pınarcıoğlu M M (2001) Nöbetleşe Yoksulluk. Gecekondulaşma ve Kent Yoksulları: Sultanbeyli Örneği [Rotating poverty. Gecekondu formations and the urban poor: the example of Sultanbeyli] İstanbul: Iletişim

Karaman O (2013a) Urban renewal in Istanbul: reconfigured spaces, robotic lives. International Journal of Urban and Regional Research 37(2):715-733

Karaman O (2013b) Urban neoliberalism with Islamic characteristics. Urban Studies

Karaman O (2014) Resisting urban renewal in Istanbul. Urban Geography 35(2):290-310

Keyder C (2005) Globalization and social exclusion in Istanbul. International Journal of Urban and Regional Research 29(1):124-134

Kumar S (2011) The research-policy dialectic: A critical reflection on the virility of landlordtenant research and the impotence of rental housing policy formulation in the urban Global South. City 15(6):662-673

Lai Y, Chan E H W and Choy L (2016) Village-led land development under state-led institutional arrangements in urbanising China: The case of Shenzhen. Urban Studies 54(7): $1736-1759$

Lawanson T (2012) Poverty, home based enterprises and urban livelihoods in the Lagos metropolis. Journal of Sustainable Development in Africa 14(4):158-171

Lawanson T and Agunbiade M (2018) Land governance and megacity projects in Lagos, Nigeria: the case of Lekki Free Trade Zone. Area Development and Policy 3(1):114-131

Lefebvre H (1991) The production of space. Oxford, UK: Blackwell

Lefebvre H (1996) Writings on cities. Oxford, UK: Blackwell

Leitner H and Sheppard E (2018) From Kampungs to Condos? Contested accumulations through displacement in Jakarta. Environment and Planning A: Economy and Space 50(2):437-456

Lin G C S and Ho S P S (2005) The state, land system, and land development processes in 
contemporary China. Annals of the Association of American Geographers 95(2):411-436

Lombard M and Rakodi C (2016) Urban land conflict in the Global South: Towards an analytical framework. Urban Studies 53(13):2683-2699

Luo G (2014) Shenzhen shi hefa wai tudi de guanli zhengce bianqian yanjiu [Unconfirmed land: policy change in Shenzhen]. Shenzhen: Haitian chuban she

Ma E X and Blackwell A (2017) The political architecture of the first and second lines. In M A O'Donnell, W Wong and J Bach (eds) Learning from Shenzhen: China's Post-Mao Experiment from Special Zone to Model City (pp 124-137). Chicago: University of Chicago Press

McFarlane C (2011) Assembling the everyday: incremental urbanism and tactical learning. Learning the City (pp 32-61). Wiley-Blackwell

McFarlane C (2012) Rethinking informality: politics, crisis, and the city. Planning Theory \& Practice 13(1):89-108

Nanfang dushibao (2003) Shenzhen chengshi hua quanmian tisu jiang chengwei quanguo shou ge wu nongcun chengshi [Shenzhen fully accelerated the policy of urbanisation and became the first city without villages]. 31 October http://news.sina.com.cn/c/2003-1031/08502038284.shtml (last accessed 4 May 2016)

Nanfang Metropolis Daily (2003) Shenzhen jiangcheng quanguo shou ge we nongun chengshi [Shenzhen will become the first city without villages]. 31 October. http://ne ws.sohu.com/29/94/news215019429.shtml (last accessed 20 June 2016)

Nanfang Zhoumo (2014) Shenzhen chengzhongcun jumin zhong fang bao di he shi xiu? [When will the chengzhongcun villagers stop illegal construction to defend their land?] 18 August http://news.officese.com/2014-8-18/75057.html (last accessed 20 June 2016)

Ng M K and Tang W-S (2004) The role of planning in the development of Shenzhen, China: rhetoric and realities. Eurasian Geography and Economics 45(3):190-211

O’Donnell M A (2017) Laying siege to the villages: the vernacular geography of Shenzhen. In M A O'Donnell, W Wong and J Bach (eds) Learning from Shenzhen: China's Post-Mao Experiment from Special Zone to Model City (pp 107-123). Chicago: University of Chicago Press

O'Donnell M A, Wong W and Bach J (2017) Introduction. Experiments, exceptions, and extensions. In M A O'Donnell, W Wong and J Bach (eds) Learning from Shenzhen: China's Post-Mao Experiment from Special Zone to Model City (pp 1-19). Chicago: University of Chicago Press

Öncü A (1988) The politics of the urban land market in Turkey: 1950-1980. International Journal of Urban and Regional Research 12(1):38-64

Oni A and Durodola D O (2010) Disputes Resolution Amongst Residents of Tenement 
Properties in Lagos, Nigeria. Global Jour. of Engg. \& Tech. 3(4):661-670

Ozdemir N (1999) "The transformation of squatter settlements into authorised apartment blocks : a case study of Ankara, Turkey." Kent, UK, University of Kent

Payne G (2001) Urban land tenure policy options: titles or rights? Habitat International 25(3):415-429

Peil M (1991) Lagos: The city is the people. London: Belhaven Press

Robinson J (2002) Global and world cities: a view from off the map. International Journal of Urban and Regional Research 26(3):531-554

Robinson J (2006) Ordinary cities: between modernity and development. London: Routledge

Robinson J (2011) Cities in a world of cities: the comparative gesture. International Journal of Urban and Regional Research 35(1):1-23

Robinson J (2016) Thinking cities through elsewhere: Comparative tactics for a more global urban studies. Progress in Human Geography 40(1):3-29

Roy A (2009a) The 21st-century metropolis: new geographies of theory. Regional Studies 43(6):819-830

Roy A (2009b) Why India cannot plan its cities: informality, insurgence and the idiom of urbanization. Planning Theory 8(1):76-87

Roy A and AlSayyad N (2004) Urban Informality: Transnational Perspectives from the Middle East, Latin America, and South Asia. Lexington Books

Sawyer L (2014) Piecemeal Urbanisation at the Peripheries of Lagos. African Studies 1-19

Sawyer L (2016) "PLOTTING the Prevalent but Undertheorised Residential Areas of Lagos. Conceptualising a Process of Urbanisation through Grounded Theory and Comparison.". Zurich, ETH Zurich

Sawyer L, Schmid C and Streule M (2020) Bypass urbanism: the reordering of urban peripheries in Kolkata, Lagos and Mexico City. Working paper. Department of Architecture, ETH Zürich.

Schmid C (2008) Henri Lefebvre's theory of the production of space: towards a threedimensional dialectic. In Goonewardena K (eds) Space, Difference, Everyday Life: Reading Henri Lefebvre (pp 27-45). London: Routledge

Schmid C (2014) Patterns and pathways of global urbanization: Towards comparative analysis. In Brenner N (ed) Implosions/Explosions: Towards a Study of Planetary Urbanization (pp 203-217). Berlin: Jovis

Schmid C (2015) Specificity and urbanization: a theoretical outlook. The Inevitable Specificity of Cities (pp 287-305). Zürich: Lars Muller 
Schmid C, Karaman O, Hanakata N, Kallenberger P, Kockelkorn A, Sawyer L, Streule M and Wong K P (2018) Towards a new vocabulary of urbanisation processes: A comparative approach. Urban Studies 55(1):19-52

Schmid C (2018) Journeys through planetary urbanization: Decentering perspectives on the urban. Environment and Planning D: Society and Space 36(3):591-610

Şenyapılı T (1992) A new stage of gecekondu housing in Istanbul. In i Tekeli, T Şenyapılı, A

Şenyapılı T (1998) Cumhuriyet'in 75. yılı, gecekondunun 50. yılı [75th anniversary of the republic, 50th anniversary of the gecekondu]. In Y Sey and Ö Derya (eds) 75 Yılda Değişen Kent ve Mimarlı [Changing architecture and the city during 75 years] (pp 301-316). Istanbul: Tarih Vakfı

Shatkin G (2017) Cities for profit: the real estate turn in Asia's urban politics. Ithaca: Cornell University Press

Shenzhen Museum (1999) Shenzhen tequ shi [History of Shenzhen Special Economic District]. Beijing: Renmin chuban she

Shenzhen Statistics Bureau (2017) Shenzhen Statistical Yearbook 2017. Beijing: China Statistics Press

Shenzhen Tequ Bao (2016) Shenzhen shi zhengzhi wei jian yao zhuanhuan silu shu du jiehe [Shenzhen city should adopt a new strategy combining clearance and blocking to control illegal construction]. 31 January

Simone A (2014) Jakarta: drawing the city near. Minneapolis; London: University of Minnesota Press

Simone A (2018) The urban majority and provisional recompositions in Yangon. Antipode 50(1):23-40

Simone A and Fauzan A U (2012) Making security work for the majority: reflections on two districts in Jakarta. City \& Society 24(2):129-149

Simone A and Rao V (2012) Securing the Majority: Living through Uncertainty in Jakarta. International Journal of Urban and Regional Research 36(2):315-335

Smith N (1996) The new urban frontier: gentrification and the revanchist city. New York: Routledge

Soliman A M (1996) Legitimizing informal housing: accommodating low-income groups in Alexandria, Egypt. Environment and Urbanization 8(1):183-194

Song Y, Zenou Y and Ding C (2008) Let's not throw the baby out with the bath water: the role of urban villages in housing rural migrants in China. Urban Studies 45(2):313-330 
Soto $\mathrm{H}$ de (2000) The mystery of capital: why capitalism triumphs in the West and fails everywhere else. New York, NY: Basic Books

Streule M, Sawyer L, Karaman O and Schmid C (2020) Popular Urbanization: Conceptualizing Urbanization Processes Beyond Informality. International Journal of Urban and Regional Research 44(4): 652-672

SUPB (2005) "Tudi guanli zhengce wenti yanjiu she hui yingxiang yanjiu [A study of land management and policy problems: a study of social impacts]." Shenzhen Urban Planning Bureau

SUPLAB (1999) "Search for a Balance in the Dynamic Change: The Evolving History of Shenzhen's Planning." Shenzhen Urban Planning and Land Administration Bureau

Tekeli i (1992) Development of urban administration and planning in the formation of Istanbul metropolitan area. In i Tekeli, T Şenyapılı, A Türel, M Güvenç, and E Acar (eds) Development of the Istanbul Metropolitan Area and Low Cost Housing (pp 3-111). Istanbul:

Turkish Social Science Association, Municipality of Greater Istanbul, IULA-EMME.

Tekeli i (1998) Türkiye'de cumhuriyet döneminde kentsel gelişme ve kent planlaması [Urban development and urban planning in Turkey in the republican era]. In Y Sey and Ö Derya (eds) 75 Yılda Değişen Kent ve Mimarlık [Changing architecture and the city during 75 years] (pp 1-24). Istanbul: Tarih Vakfi

Tercan B (2018) 1948'den bugüne imar afları [Zoning amnesties from 1948 to present]. Mimarlik 403:20-26

Towry-Coker L (2011) Housing Policy and the Dynamics of Housing Delivery in Nigeria. Lagos State as Case Study. Ibadan: MakeWay Publishing Ltd.

Türkün A (ed) (2014) Mülk, Mahal, insan: istanbul'da Kentsel Dönüşüm [Property, Locality, People: Urban renewal in Istanbul]. Istanbul: Istanbul Bilgi University Press

UPDIS (Urban Planning \& Design Institute of Shenzhen) and UESPKU (Urban Environmental Sciences of the Peking University) (1998) Shenzhen shi tequ wai tudi shiyong yu guanli yanjiu [a study of land-use and management outside of the Shenzhen Special Economic District - the case of Bao'an district]. Chengshi guihua yanjiu suo 1998 nian chengguo xuanbian - yanjiu baogao [Research reports of Urban Planning Institute 1999] (pp 17-49). UPDIS

Vaughan O (2000) Nigerian chiefs: traditional power in modern politics, $1890 s-1990$ s. Rochester, NY: University of Rochester Press

Wang Y P, Wang Y and Wu J (2009) Urbanization and informal development in china: urban villages in Shenzhen. International Journal of Urban and Regional Research 33(4):957-973

Wang Y P, Wang Y and Wu J (2010) Housing migrant workers in rapidly urbanizing regions: a study of the Chinese model in Shenzhen. Housing Studies 25(1):83-100

Williams B A (1975) The federal capital: changing constitutional status and intergovernmental 
relations. In A B Aderibigbe (ed) Lagos. The Development of an African City (pp 59-78). London: Longman Nigeria

Yonder A (1987) Informal land and housing markets: the case of Istanbul, turkey. Journal of the American Planning Association 53(2):213-219

Yonucu D (2008) A story of a squatter neighborhood: from the place of the "dangerous classes" to the "place of danger." Berkeley Journal of Sociology 52:50-72

Zerah M-H and Denis E (eds) (2017) Subaltern Urbanisation in India: An Introduction to the Dynamics of Ordinary Towns. New York, NY: Springer, India, Private Ltd

Zhang L, Zhao S X B and Tian J P (2003) Self-help in housing and chengzhongcun in China's urbanization. International Journal of Urban and Regional Research 27(4):912-937

Zhang Li (2005) Migrant enclaves and impacts of redevelopment policy in Chinese cities. In Ma L J C and Wu F (eds) Restructuring the Chinese city: changing society, economy and space (pp 218-233). London; New York: Routledge

i This project started in 2011 in the framework of Future Cities Laboratory (FCL), SingaporeETH Centre and the Chair of Sociology, Department of Architecture at ETH Zürich. The research team included Christian Schmid, Ozan Karaman, Naomi Hanakata, Pascal Kallenberger, Anne Kockelkorn, Lindsay Sawyer, Monika Streule, Rob Sullivan and Kit Ping Wong. A brief outline of plotting urbanismalongside other concepts-was presented in the comprehensive introductory paper of the project (Schmid et al. 2018:37-41).

ii Although Kolkata formed an important part of the comparative discussions and conceptualisation of the process of plotting, the case study is not included here due to restrictions of length (see Schmid et al 2018).

iii We elaborate on these difficulties in more detail in Streule et al (2020)

iv For instance, some level of commercialization and certain tenant-ownership relations often already accompanies popular urbanization (see Gilbert 1983).

$\checkmark \quad$ We thank AbdouMaliq Simone for proposing the last connotation of plotting.

vi From interviews during November 2014, Lagos. All names throughout the paper are pseudonyms. All exchange rates as of 2014.

vii The Lagos region is divided between the "mainland" and the "central district" (see below).

viii Omo Onile is a Yoruba term; it literally means "son/child of the soil/land".

ix Because only very few people can get a bank loan, people save over a long period of time, and often borrow smaller loans from religious, ethnic or hometown membership groups (Esusu savings groups). In this way, plotowners are already established in the area or in a membership group by the time they build.

$\mathrm{x} \quad$ For instance: high capacity generators or cheap ones; private boreholes or buying water from vendors; employing a live-in security guard or putting a gate across the end of the street at night (see Sawyer 2014 for more detail).

xi The "central district" includes Lagos Island, Victoria Island and Lekki Peninsula as well as Apapa, Ebute Metta, Yaba and the University of Lagos on the mainland side. "Lagos mainland" here refers to the contiguous urban area beyond the central district. We use these two names here because official names for these areas changed frequently with different political regimes.

xii The urbanization of the Lekki peninsula is an example of "bypass urbanism": another concept formulated through our comparative project referencing Lagos, Kolkata and Mexico City (see Sawyer et al 2020).

xiii Fieldnotes, September 28, 2014. 
xiv "Gecekondu” means "built over night".

xv See also Payne 2001 on the effects of tenure legalization policies on vulnerable groups.

xvi Fieldnotes, August 30, 2013.

xvii In 1994 Shenzhen’s administrative rank was designated as “deputy-provincial."

xviii At the time, about 46,000 villagers were registered in 173 villages within the SED (Shenzhen Museum 1999:383-384).

xix Information given in an interview with a planner from Shenzhen, October 2014. This can be also found in a speech by the then Shenzhen municipal party secretary (see Nanfang dushibao 2003) and in local documents (see Luo 2014).

$\mathrm{xx} \quad$ A total of 18 towns, 218 village collectives and 270'000 villagers were concerned in this measure (Nanfang Metropolis Daily 2003).

xxi Interview with a Shenzhen planner, 2015.

xxii In the entire city of Shenzhen, between 1999 and 2004, the total number of illegal buildings (residential and industrial) grew from 240'000 to 350'000 (SUPB, 2005). Until 2014, the total number of illegal buildings (residential and industrial) was $373^{\prime} 000,87 \%$ of which were located in the areas outside the SED (Shenzhen Tequ Bao 2016).

xxiii Fieldwork in some villages outside the former SED border from 2013 to 2015

xxiv We would like to thank Nitin Bathla and Marie-Hélène Zérah for advising us on this relationship. 